Original Research Paper

\title{
The Development of Learning Devices Based on Guided Inquiry and Affectivities for Students' Critical Thinking Skills
}

\author{
Lita Sumiyarti $^{1 *}$, Dadi Setiadi ${ }^{1}$, Jamaluddin $^{1}$ \\ ${ }^{1}$ Master of Science Education Program, University of Mataram, Lombok, West Nusa Tenggara, Indonesia
}

\author{
Article history \\ Received: May $27^{\text {th }} 2019$ \\ Revised: June $20^{\text {th }} 2019$ \\ Accepted: July $10^{\text {th }} 2019$ \\ *Lita Sumiyarti: Master of \\ Science Education Program, \\ University of Mataram, \\ Lombok, West Nusa \\ Tenggara, Indonesia; \\ Email: $\underline{\text { litasumi@gmail.com }}$
}

\begin{abstract}
The purpose of this research is to make the learning device based on guided inquiry in science learning and affectivities to improve students' critical thinking skills and to examine its validity, effectiveness, and practicability. This research adapts Borg \& Gall Research and Development and modification. The instruments of the research were instrument validation results, practicality, and effectiveness. Data were collected by employing a validation sheet that was validated by the assessor to gain validation and practicality scores, the student's positive response questionnaire and learning result test sheet were full filled-in by the students, and the observation sheet was full filled-in by the observer. The average score of total validity is in the score range of $2.6<\mathrm{SV} \leq 3.5$ and is an invalid category. The result of practicality research of learning devices based on practicality questionnaire the range of 3.5-4.0 and is in a very practice category. The result of effectiveness based on learning result test showed that $75 \%$ of the students are completely based on the results of the research, it can be concluded that the learning device based on guided inquiry is valid, practical, and effective that is feasible to be used in a learning activity in the classroom.
\end{abstract}

Keywords: Development Research; Guided Inquiry; Critical Thinking Skill.

\section{Introduction}

The developments in science and technology are increasing rapidly. It causes the flow of information is quick and without limits. This has a direct impact on many areas of life, including in education. One of the branches of knowledge in the field of education is the sciences. Science is a collection of systematically arranged knowledge and its use is generally restricted to natural phenomena. The learning objectives in science need to be achieved by strategies that can lead students to learn actively so that learning becomes meaningful and provide experiences to students (Joyce et al., 2011).

The Activeness of science learning divided into two aspects, namely the act active physically and thinking active (NRC, 1996). Learning science holds a very important role in building the character of students. These conditions require the learning of science with good quality in order to follow the development of science in society. Learning science who full of thinking activities thought to be a vehicle to train learners in order to master the knowledge, concepts, principles of natural science has the ability to build critical thinking skills and other scientific capabilities that can improve the quality of human resources.

The survey results in PISA and TIMSS international institutions are used as the basis for the government to encourage character education in the world of education. One of the government's policy is to develop a new curriculum is the curriculum of 2013. Through this curriculum change in government expects their mental revolution on students.

The curriculum currently implemented in 2013 are expected to carry the next generation of productive, creative, innovative and character. In practical terms, the curriculum in 2013 by Abidin (2014) is learning that requires students to compose a learning experience to work scientifically. Therefore, learning in the context of the curriculum in 2013 to build on the scientific approach. Students need to be encouraged to work to solve problems, find everything for himself and strive hard to realize his ideas in order to understand and can apply their own knowledge.

The results of a preliminary study in class VIII of Pringgarata 1 Junior High School showed 
that teachers lacked training in students' scientific abilities such as critical thinking skills. Students tend to answer the question by quoting books or other library materials without the express opinion or analysis of this opinion. If this situation continues, the students will have difficulty applying the knowledge acquired in the classroom and real life. Learning in the classroom only to obtain test scores and test scores are not necessarily relevant to their level of understanding. There are still many students who have a low value, it can be seen from the average score science learning achievement is low (under at 65).

The learning process takes place dominated by teachers. The teacher only transfers products and memorize science as actual information. They need to activate the student's science abilities by selecting the appropriate learning models. So, the students can receive the material they are learning easily. One model of learning in accordance with the scientific approach or scientific inquiry and effectiveness against critical thinking skills is a guided inquiry learning model.

Guided inquiry-based learning involves students to seek information and make explanations from direct experience with teacher guidance (Chiappetta and Koballa, 2010). Guided inquirybased learning provides direct experience to students. Through direct experience, students can find facts, so that they can learn to find knowledge, train science process skills, ability to think critically.

Sanjaya (2010) stated that this inquiry learning strategy emphasizes the process of seeking and finding. Teachers do not provide material or concept directly to the students, but students who seek and find their own materials and concepts of the lesson.

Teachers also need to develop learning tools because they are an important part of supporting the learning process and need to be prepared early. Learning devices are equipment in the form of a set of media or facilities used by teachers and students as instructions and guidelines in the learning process in the classroom. Well-prepared learning tools can achieve learning goals and also make the learning process more effective. The learning device owned by teachers needs to build the capacities of students such as critical thinking skills. This is all done with the aim to improve the quality of education, especially in the field of science.

Based on the description of the background above, the problem in this research is how the effectiveness of the device guided inquiry-based science learning to the critical thinking ability of students of Pringgarata 1 Junior High School. The purpose of this study was to determine the effectiveness of learning by using guided inquirybased science learning tools for students' critical thinking skills.

\section{Method}

Subjects tested in this study are students in the first year. Further research quasi-experimental design with pretest and posttest control group design. These samples included 64 people who were scattered in two classes. Analysis of learning device data in this study includes validity, practicality, and effectiveness.

The validity test of this device includes the syllabus and Learning Implementation Plan and Student Activity Sheet. Before the instruments compiled by researchers were tested in schools, instrument validation was carried out first by experts using the Delphi method stages. After the instrument is validated by experts, then each instrument is analyzed for its feasibility by using the average score as a reference.

Table 1. Categorizing Criteria for the Results of Research Instrument Validation

\begin{tabular}{lll}
\hline Interval & Category & Description \\
\hline $1.0 \leq \mathrm{SV} \leq 1.5$ & Not good & $\begin{array}{l}\text { Not yet usable, } \\
\text { requires } \\
\text { consultation } \\
\text { Can be used with } \\
\text { many revisions } \\
\text { Can be used with } \\
\text { a slight revision } \\
\text { Can be used, } \\
\text { without revisions }\end{array}$ \\
\hline
\end{tabular}

(Source: Ratumanan and Laurens, 2011)

Practical measurement using the observation sheet or observation that is given to the observer.

Table 2. Practical criteria

\begin{tabular}{lll}
\hline Value & Interval Score & Category \\
\hline A & $3.5-4.0$ & Very practical \\
B & $2.5-3.5$ & Practical \\
C & $1.5-2.5$ & Quite practical \\
D & $1.0-1.5$ & Less practical \\
\hline
\end{tabular}

(Source: Dewi, et al (2013)

Analysis of the effectiveness of a science learning worksheet can be seen from the learning outcomes test, namely the ability to think critically. Individual learning completeness, if students get the 
maximum completeness criteria value set by the school. The maximum completeness criteria set by the school for science lessons is 65.

Based on the pretest and posttest scores of students' critical thinking skills, the $\mathrm{N}$-gain data of each student can be calculated to see an increase in critical thinking skills before treatment and after treatment using the equation:

$$
N-\text { Gain }=\frac{\text { Postest }- \text { Pretest }}{\text { Max Score }- \text { Pretest }}
$$

(Hake, 2007)

\section{Result and Discussion}

Products such as the learning device produced through the research and development with reference to the model developed by Borg and Gall (1983).

\section{The Validity of Learning Tool}

Prior to the initial design of the learning device science-based, guided inquiry tested, first validated by experts. Validation is intended to determine the feasibility of the results of the initial design of the device. Validation is expertly done by four people. The results of the validation by experts can be described in Table 3.

Table 3. The Results of Validation Learning Tool

\begin{tabular}{lll}
\hline Aspect & $\begin{array}{l}\text { The average } \\
\text { percentage }\end{array}$ & $\begin{array}{l}\text { Level } \\
\text { Valditas }\end{array}$ \\
\hline Syllabus & 3.27 & valid \\
RPP & 3.48 & Valid \\
Student work sheet & 3.27 & Valid \\
\hline
\end{tabular}

The tests developed the learning tools category valid. According to Rochmad (2012) as a valid learning tool if it meets the criteria content validity and constructs validity. While Suhartini et al. (2016) state that a device with a very valid category can be used in research with revised in accordance with the advice of experts.

\section{Practicality Learning Tool}

Practicality learning device measured from the observation by the observer at the time of the study, where the observer will assess the level of adherence to the device. In addition to the above two things practicality learning device also measured the response of learners towards learning device that also will be supporting data practicality guided inquiry-based learning tool developed by researchers.

Table 4. The Results of Practicality Learning Tool

\begin{tabular}{lll}
\hline Instrument & Average & Category \\
\hline $\begin{array}{l}\text { Students responses to } \\
\begin{array}{l}\text { Student Work Sheet } \\
\text { Teacher responses to }\end{array}\end{array}$ & 3.16 & Practical \\
$\begin{array}{l}\text { Student Work Sheet } \\
\text { Observations the uses of }\end{array}$ & 3.09 & Practical \\
$\begin{array}{l}\text { Lesson Plan } \\
\text { Students responses the use } \\
\text { of student work sheet } \\
\text { Teachers responses the use } \\
\text { of student work sheet }\end{array}$ & 3.28 & Very good \\
\hline
\end{tabular}

Field trials conducted on a group of learners targeted use of the product. At this stage of the products that have been produced piloted or implemented to streamline critical thinking skills.

Based on data showing that the preliminary activities, aspects of delivering learning objectives/ indicators, motivating the students got very good rating categories. This illustrates that educators emphasize very well to the learners that are characteristic of learning Inquiry-guided, but at the beginning of the meeting the values obtained with both categories are due at the beginning of the meeting the students are still adapting to the learning activities different to the activities normally, so that students have not fully concentrated on teaching and learning. At the core activities that include phase identification and formulation of the problem, hypothesis formulation, data collection, interpretation of data and the development of the conclusions included in the excellent category. It shows that learners can follow each stage of learning very well although at the beginning of the meeting the students also require adaptation of the same as in the preliminary stages to adjust to the learning process as usual. The final stage is the final activity that includes aspects of the conclusions, summaries, and information to learners with very good category.

According to Hanz and Rohaeti (2015) study provides information on how the percent of teachers' activities carried out as syntax inquiry. If the average percentage of $80.0 \%$ over the enforceability of inquiry learning is in excellent condition. According to Nieveen (1999) if all components of the device can be fully applied learning, the learning device can be said to be practical.

\section{Effectiveness Learning Tool}

The effectiveness of the learning device obtained from critical thinking skills tests conducted by students at the end of the study 
session prior to the distribution of questionnaire responses of learners. Critical thinking skills test in the form of about the description with five numbers that matter-because had been declared invalid by the expert.

Table 5. The Results of Students' Critical Thinking Skill

\begin{tabular}{llll}
\hline \multirow{2}{*}{ Class } & \multicolumn{2}{c}{ Critical Thinking Skills } & \\
& N-Gain & Criteria & Information \\
\hline VIII C & 0.58 & Medium & Effective \\
VIII E & 0.61 & Medium & Effective \\
Average & & & \\
Category & 0.60 & Medium & Effective \\
\hline
\end{tabular}

To measure the effectiveness of the products are made, can be seen from the aspect of learners' achievement test. Effectiveness criteria are if learners achieve mastery greater than or equal to $(75 \%)$. Thus, based on trials that have been done then the criteria of effectiveness achieved with the number of learners who achieve mastery as much as the number of students, or about $75 \%$, which is reinforced by the results of research Narni et al, (2013) sustainable that learning is guided inquiry has advantages compared to right with the conventional learning, because in inquiry learners always trained to make observations, to solve problems related to the environment and cannot be separated from the material science.

The effectiveness of the learning outcomes of guided inquiry obtained by the researchers in line with previous studies conducted by Japa et al (2014), that the application of learning models of guided inquiry significant effect on skills critical thinking skills and research Megasari et al, (2014) the application of the model-guided inquiry learning a significant effect on the ability of students' critical thinking skills.

\section{Conclusion}

Based on the results of research and discussion, we can conclude that the device is guided inquiry-based learning by adapting the development of Borg and Gall with the load characteristics of the stages of guided inquiry learning models, namely the formulation of the problem, formulating hypotheses, searching for information and data, generalizations and conclusions. Product development quality criteria in this study included a test of validity, practicality, and effectiveness. A guided inquiry-based learning tool that was developed in the category valid. The trial results based on data enforceability of learning shows that learning devices that are in the very good category. Guided inquiry-based learning tool proven effective against critical thinking skills of learner.

\section{References}

Abidin, Y. 2014. Desain Sistem Pembelajaran dalam Konteks Kurikulum 2013 Bandung: Refika Aditama.

Chiappetta, E., L., and Koballa, T., R., Jr. 2010. Science instruction in the middle andsecondary schools (7thed). Boston, MA: Pearson Education, Inc.

Dewi, S., dan Ristiati. 2013. Pengembangan Perangkat Pembelajaran IPA Terpadu Dengan Setting Inkuiri Terbimbing Untuk Meningkatkan Pemahaman Konsep Dan Kinerja Ilmiah Siswa. e-Journal Program Pascasarjana Universitas Pendidikan Ganesha, 3(1).

Hake, R., R. 2007. Design-based research inphysics education: a review. American Journal of Physics. 2(1).

Hanz, D., A., Rohaeti, E. 2015. Inquiry-Based Science Learning Tool to Enhance Critical Thinking Skills and Attitude Scientific Students. Journal of Science Education Innovation. 1(2), 138-152.

Japa, L., Ramdani, A., dan Rahmayanti, F. 2014. Pengaruh Penerapan Inkuiri Terbimbing terhadap Kemampuan Kemampuan berpikir kritis Siswa Kelas XI Peminatan Matematika dan Ilmu- Ilmu Alam SMAN 2 Gerung. Universitas Mataram.

Joyce, B.,Weil, M., Calhoun, E. 2011. Model of Teaching. Model-Model Pengajaran. Terjemahan Farid, Achmad Dan Mirza, Arcilla.Yogyakarta: Pustaka Belajar.

Megasari, Ahmad, A., Pramudiyanti. 2014. Pengaruh Model Pembelajaran Inkuiri Terbimbing Terhadap Kemampuan Kemampuan berpikir kritis. Jurnal Bioterdidik, 2(5)..

Narni, L., D., Dantes, N., and Wayan, S., I. 2013. Pengaruh Model Pembelajaran Inkuiri Terbimbing Terhadap Sikap Ilmiah dan Hasil Belajar IPA. PENDASI: Jurnal Pendidikan Dasar Indonesia. 3(1).

National Research Council. 1996. National science education standards. Alexandria, VA: National Academic Press. 
Nieveen, N. 1999. Prototyping to Reach Product Quality. Design Approachesand Tools in education and Training. London: Kluwer Academic Publisher.

OECD. 2013. PISA 2012 Assessment and Analytical Framework. OECD Publising Online. Diakses di http://www.oecd.org/pisa/pisaproducts/PISA 2012 framework ebook_final.pdf. $265 \mathrm{hlm}$

Ratumanan, T., G., dan Laurens, T. 2011. Penilaian Hasil Belajar pada Tingkat Satuan Pendidikan Edisi 2 .Surabaya: Unesa University Press

Rochmad. 2012. Desain Model Pengembangan Perangkat Pembelajaran Matematika. Jurnal Kreano. 3(1), 59-72.

Sanjaya, W. 2010. Strategi Pembelajaran Berorientasi Standar Proses Pendidikan. Jakarta: Prenada Media

Suhartini, E., Supardi, I., Agustini, R. 2016. Pengembangan Perangkat Model Inkuiri Terbimbing Berbantuan Teknik Mind Mapping untuk Meningkatkan Penguasaan Konsep dan Kemempuan Berpikir Kreatif Siswa SMP. Jurnal Pendidikan Sains Pascasarjana Universitas Negeri Surabaya. 5 (2), 892-902.

Uswatun, D., A., dan Rohaeti, E. 2015. Perangkat Pembelajaran IPA Berbasis Inkuiri Untuk Meningkatkan Critical Thinking Skills dan Scientific Attitude Siswa. Jurnal Inovasi Pendidikan IPA. 1(2), 138-152. 